\title{
Želimir Žilnik and Eastern European Independent Cinema
}

The vast majority of literature devoted to independent cinema focuses on American film production. When I was looking for books on independent cinema in my university library, out of about twenty five, I identified twenty or so devoted exclusively to American cinema. For the majority of scholars and students, using the term "independent" means independent from Hollywood, not only in terms of financing and distribution, but also in style and ideology. "Independence" thus cuts across all aspects of a film's life: production, distribution and text. An American independent film tends to have a low-budget, is viewed in smaller venues (such as university campuses) than block-busters, addresses a more sophisticated audience, breaks with genre conventions, rarely uses stars, diverts from a smooth narrative, and displays a critical attitude to the dominant ideology. Such a definition, however, carries many problems, as it assumes "dependent" cinema as being monolithic, while in reality it is heterogeneous. Thus, few independent films "tick all the boxes" of independence, leaving critics to decide which aspect of the film to privilege.

Nevertheless, in most publications, independence manifested through a film's text is prioritised. For example, Scott Macdonald gave the title A Critical Cinema to his book of interviews with leading figures in American independent cinema, and announced in the introduction that "One of the goals of these critical filmmakers has been to place our awareness and acceptance of the commercial forms and their highly conventionalized modes of representation into crisis." [1] Independent filmmakers often make films about independent and "dependent" filmmaking and, in a wider sense, about the status of art. Elsewhere, Macdonald underscores the link between independent cinema and individual authorship. Independent filmmakers "often appear personally with the films, just as poets traditionally travel to read their works." [2] It is the norm to regard independent filmmmakers as auteurs, as demonstrated by the fact that publications on this topic privilege filmmakers over films, as in the previously quoted three-volume work by Scott Macdonald or in "American Independent Cinema: A Sight and Sound Reader," which includes sections such as "Pioneers," "African Americans," "Queers" and "Miniaturists and Minimalists." [3]

[1] S. Macdonald, A Critical Cinema: Interviews with Independent Filmmakers, University of California Press, Berkeley 1988, p. 1.

[2] Ibidem, p. 6.
Images vol. XIII/no. 22 Poznań 2013 ISSN 1731-450X
The concept of independent cinema in the West and in the East
[3] J. Hillier, American Independent Cinema: A Sight and Sound Reader, British Film Institute, London 2001. 
Unlike in the West, the idea of independent cinema in the East during the communist period was rarely used. This was because under the communist system, the state monopolised the production and distribution of films; hence the possibilities for making and showing films outside the prescribed institutional framework were limited. However, it did happen on occasion, or at least there were cases when films were pronounced independent. One such example was Rysopis (Identification Marks: None, 1964) by the Polish director Jerzy Skolimowski. He made the film while he was a student at the Łódź Film School, using pieces of reel allocated to him to shoot short exercises, so-called student etudes, to produce a full-length feature film. Its author, of course, made use of state funding, and Identification Marks: None was later distributed as a "normal" film, but it was made outside the normal channels of production, and hence acquired its "independent" status. Equally, the widespread cine-club movement, which flourished particularly on student campuses, was regarded as a means of fulfilling audiences' appetite for independent cinema, which meant being able to watch and debate films without political interference. Some films shown at such screenings were homemade $8 \mathrm{~mm}$ films, often with political message.

In contrast to "independent cinema," the term "dissident cinema" was used often in the Eastern European context. It referred to films which were produced within the socialist institutional framework, but came across as critical of the dominant ideology. It also included the work of those filmmakers who, finding themselves unable to make the kind of films they wanted to or having their films shelved, decided to emigrate. In the Polish context, Jerzy Skolimowski is again a case in point, as after not giving into demands to cut a contentious episode from his film Ręce do góry (Hands Up!, 1967/1985), he decided not to make more films in Poland and embarked on a career abroad.[4] For some critics, using any subversive message in a film, even a sublime one, was sufficient to count the film as dissident. In line with this reasoning, Andrzej Wajda in Poland and Dušan Makavejev in Yugoslavia were considered dissident filmmakers. But others argued that a specific filmmaker was able to make and exhibit films in his/her own country proved that s/he was not a dissident. Only those filmmakers whose work was shelved and/or who were forced to emigrate fit this description. We thus see that dissident cinema in the East, not unlike independent cinema in the West, is scalar and relative to a specific context. What qualified as dissident in one country and period might not be viewed as dissident in another country and moment of time. This is because with the passage of time the patterns of censorship changed, as did the opportunities to work abroad. Almost everywhere in Eastern Europe what was absolutely forbidden in the 1950s was widely accepted in the 1980 .

[4] E. Mazierska, Jerzy Skolimowski: The Cinema of a Nonconformist, Berghahn Books, Oxford 2010, p. 21. 
The importance of dissidence in the socialist context can be in large part explained by the significance of culture under socialism. As Gal Kirn observes, due to the inaccessibility of the official "loci" of power (political apparatuses such as, most importantly, parties) for ordinary people, many political and economical struggles were translated and displaced to the sphere of culture.[5] This "culturalisation" of antagonism in the last instance produced new public spaces and phenomena, such as mass audiences of non-mainstream films conveying explicit political messages, an example in Poland being the films of Andrzej Wajda, such as Popiót i diament (Ashes and Diamonds, 1958), and in Yugoslavia certain Black Wave films.

Dissident cinema had a somewhat different inflection in each socialist country, depending on the level of censorship, the opportunities of artists to travel abroad, and the international standing of the filmmaker at hand. It was widely, albeit unofficially, known that almost each socialist country had an "official" dissident or even several artists fitting this description. This oxymoron refers to the phenomenon of the state allowing and even promoting some subversive work as a means to vent the anger of its population and to show to the world that it allowed freedom of expression. Awards at prestigious international festivals for directors such as Konrad Wolf, Andrzej Wajda and Dušan Makavejev proved that this strategy worked. The world appreciated their films. and this appreciation helped to overcome or soften the "totalitarian" image of the socialist countries.

The relation between dissident and official art was further complicated by the fact that subversive art was created from different ideological perspectives: right and left-wing, internationalist or nationalist, socially engaged or disengaged, realist or surrealist. Wolf was a different dissident than Wojciech Has, and Wajda differed from Makavejev. It is in the context of the heterogeneity of dissident cinema and independent cinema at large and the changes experienced by Eastern Europe after the Second World War that I shall locate the work of Želimir Žilnik.

Following the break with the Soviet Union in 1948, in $1950 \mathrm{Yu}-$ goslavia opted for self-managed socialism, or self-management, namely a system of autonomous cooperative enterprises. [6] In some way, this system was closer to the Marxist ideal than the crude communism practiced in countries such as the Soviet Union or Bulgaria, by allowing workers more power at the factory level; yet, in another way, it was closer to capitalism, by accepting unemployment as an inevitable by-product of an efficient economy. One consequence of such an approach was Yugoslav citizens being allowed the freedom to travel abroad, a privilege that had been withdrawn in other socialist countries. The borders were

[5] G. Kirn, "From the Primacy of Partisan Politics to the Post-Fordist Tendency in Yugoslav Self-Management Socialism," [in:] Post-Fordism and its Discontents, ed. G. Kirn, Jan van Eyck Academie, Maastricht 2010.
[6] J.B. Allcock, Explaining Yugoslavia, Hurst and Co., London 2000, pp. 76-78.
The case of Yugoslav cinema and Žilnik 
open primarily for the unemployed to leave to find jobs in the West, and in this way, support their families back in Yugoslavia. The capital earned by the Yugoslav Gastarbeiter was one of the crucial elements of the country's economy. The Gastarbeiter was thus dubbed "the seventh republic": Yugoslavia encompassed six republics, with a seventh, made up of economic emigrants, being situated abroad.

Gal Kirn argues that due to its focus on individual responsibility and entrepreneurship, and the importance attributed to the knowledge economy, self-management anticipated a post-Fordist type of capitalism. [7] The creative personnel associated with the process of filmmaking (directors, cinematographers, screenwriters), working as freelance professionals, rather than, as in other socialist countries, being chained to the centrally funded studios, confirmed this idea.[8] Moreover, while in the majority of Eastern European countries film studios were located in the capital cities, in Yugoslavia they were de-centralised: located in different republics, and in the case of Serbia, even in different cities. Yugoslav filmmakers under self-management, having more political yet less financial freedom than their colleagues in the rest of Eastern Europe, yet still enduring political censorship, were situated somewhere between American independent cinema and socialist dissident cinema.

This is especially the case in the late 1960s and mid-1970s, when Želimir Žilnik began his career: the period of a flourishing Yugoslav New Wave, known also as the Black Wave or Black Film, still regarded as the most important phenomenon in Yugoslav cinema and the main source of its international renown, both for its artistic quality and its political courage. This movement epitomised Yugoslav cinema's independence from the clutches of earlier paradigms, most importantly the state-sponsored Partisan Film of the 1950s and 1960s, which concerned the heroism of Yugoslav partisans liberating their country from fascists during the Second World War.

The division between documentary and feature filmmaking during the Black Wave in Yugoslavia was less rigid than elsewhere in the socialist world. This was largely due to lower budgets, the expectation that filmmakers could return to the documentary form if they failed to secure sufficient resources to make a full-length film, and, perhaps, opposition to the highly staged, high-budget, epic and politically conformist Partisan Films. Many films were shot on location in natural interiors, industrial plants or disused factories, and we see in them people playing themselves and looking straight into the camera. The style frequently switches - from a story centred on an individual protagonist to a scientific or pseudo-scientific examination of a specific aspect of social life, with extraneous material inserted to illuminate the point. The master of this hybrid form, often described as an essay film, the model for which in Western cinema of the 1960 s was Jean-Luc Godard's Vivre sa vie (1962), was Dušan Makavejev. By using such a style, characteristic

[7] G. Kirn, From the Primacy of Partisan Politics...

[8] P. Levi, Disintegration in Frames: Aesthetics and
Ideology in the Yugoslav and Post-Yugoslav Cinema, Stanford University Press, Stanford 2007, p. 15. 
of a certain strand of independent cinema from all around the world (Chris Marker is today regarded as its leading representative), Yugoslav directors purposefully or not inscribed themselves into this tradition.

Želimir Žilnik encapsulates these trends. He was born in Serbia in 1942 and got his first working experience in 1960 in his hometown of Novi Sad as the chief editor of a local cultural group/publication called Youth Forum. He wrote film criticism and became active in the Novi Sad Ciné-club, where he made experimental short films in the mid1960 s. Later on he cut his teeth in the world of feature production by working as an assistant director for Dušan Makavejev. His full-length feature debut, Rani radovi (Early Works), made in 1969, is regarded as one of the main examples of the Yugoslav New Wave. Early Works received the main award, the Golden Bear, at the Berlin Film Festival. This prestigious award, however, did not help the director to preserve his creative independence in Yugoslavia, as Early Works was banned there and Žilnik, unable to make more films in his native country, was forced to emigrate. He went to West Germany, where he made a number of documentaries, again as an independent director. One of them proved contentious, which led to his return to Yugoslavia in the mid-1970s, to work in television and as a documentary filmmaker. In the early 1990s, Žilnik witnessed and documented the dissolution of his country in a number of acclaimed documentaries. He continues his career now as a Serbian director under a new political and artistic regime - that of postcommunism or neoliberal capitalism. As the only director from the original Black Wave who is still active, and one who has had substantial experience with different cinematic regimes - Western and Eastern, capitalist and socialist - Žilnik can serve as a perfect case study to investigate various types of independence, as well as to examine the complex link between independence and transnationality. His career shows that filmmakers enjoy greater political freedom if they have the ability to travel and work abroad, but this opportunity comes at the price of having to adjust to different production, distribution and exhibition regimes and to the tastes of varied audiences.

I will risk the statement that such an adjustment came to Žilnik's easier than to many other directors. This is because Yugoslavia, where he began his career, can be seen as a continuation of the Habsburg Empire as a place which allowed, and even encouraged cultural diversity and hybridisation. On the other hand, for most of his life he dwelled in Novi Sad, the most ethnically mixed part of the former Yugoslavia, which can be regarded as a microcosm of the Habsburg Monarchy, not least because the people in this area represent a level of cultural and linguistic diversity unknown in other regions of Europe. Finally, as a lawyer by profession, Žilnik was able to defend himself in court when his work put him on a collision course with authorities, and helped him adjust to different production regimes.

In the subsequent parts of my investigation, I will focus on three films, coming from different periods of Žilnik's career and representing 
different models of independent cinema: Early Works, Inventory and Old Style Capitalism. The bulk of my discussion will be devoted to the last film, as it best reveals Žilnik's method and his Weltanschauung.

\section{Early Works}

As I have already mentioned, film production in Yugoslavia, unlike in other socialist countries, was decentralised. Žilnik was linked to the Neoplanta Studio in Novi Sad, in Vojvodina. Neoplanta was founded after it was realised that Vojvodina had the most advanced and developed cinema network in Yugoslavia and a very active amateur cinema club scene, but no professional film production unit. It was established in 1966, and Svetozar Udovički was appointed its first director.

Initially, Neoplanta focused on the production of short films. Through Žilnik, who was from Novi Sad, many established authors, such as Dušan Makavejev, started making films for Neoplanta. There he shot his full-length debut, Early Works. In making this film, Žilnik enjoyed significant political freedom and one of the largest budgets in his career, about 130,000 USD, which was still rather modest in comparison with those enjoyed by Partisan films. However, according to Žilnik, his film was financed not by the funding Neoplanta received from state and regional institutions, as would have been the case in Poland or, indeed, elsewhere in Yugoslavia, but by a bank loan. The head of Neoplanta demanded from the director to make a film so good that it would repay the loan and make a profit.[9] This proved to be the case - the film was very successful, earning a profit of about 650,000 USD.[10]

The film's subject is an investigation by a group of young people, consisting of three men and one woman named Yugoslava, of the implementation of socialist principles in the Yugoslav countryside. Such a subject, in my view, reflects Žilnik's ideological independence. As opposed to the filmmakers of the earlier generation, for whom socialist realism was a master code, and who typically neglected the reality of living under socialism, and unlike his contemporaries in other socialist countries, such as Poland and Czechoslovakia, who avoided tackling socialist principles altogether, Žilnik's vantage point is the socialist ideals of equality, solidarity and freedom, and his goal is to find out if and how these ideals are being fulfilled in Yugoslavia. He thus confronts reality with concrete experience. Žilnik draws attention to film language as a specific signifying practice, rather than as a direct expression of reality, in a way that brings to mind the debates in the 1960s and 1970 s about realism and ideology in cinema that were often conducted in response to Godard's films. Žilnik does not want his audience simply to see "how things are," but to also be aware that what they are seeing

[9] This and much additional information concerning details of the production of Žilnik's films came directly from the filmmaker.

[10] G. Kirn, "New Yugoslav Cinema - A Humanist
Cinema? Not Really,' [in:] Surfing the Black: Yugoslav Black Wave Cinema and Its Transgressive Moments, ed. G. Kirn et al., Jan van Eyck Academie, Maastricht 2012, p. 17. 
is mediated by language. This idea is announced early in the film, when we learn that the characters have created a political theatre, bringing to mind Bertolt Brecht's concept of "epic theatre." Brecht wrote that epic theatre's "spectator was no longer in any way allowed to submit to an experience uncritically (and without practical consequences) by means of simply empathy with the characters in a play. The production took the subject-matter and the incidents shown and put them through a process of alienation: the alienation that is necessary to all understanding." [11]

Watching Žilnik's film we get a "Brechtian" feeling of not getting what one expects and, hence, unease. The characters assign themselves the typical socialist realist roles of pioneers, who go to the periphery in order to enlighten the ignorant masses. However, they demonstrate that they themselves need enlightenment. Their trip into the depths of the countryside also shows that the socialist project is unable to sever the present from the past, because the past is inscribed in the country's material culture and shapes the identities of its inhabitants, and therefore keeps returning at every turn. This is conveyed in the story of an old man who reminisces about the time he spent in Siberia during the period of the Habsburg Empire and the German inscription on agricultural machines discovered by young travellers pointing to the fact that Germans once lived on the territory of Yugoslavia and, in a wider sense, that the country of the Southern Slavs comprised other nations which contributed to its culture and prosperity. Thus, by showing the lack of Germans on the territory traversed by the group, Žilnik alludes to the material and discursive cleansing of "foreign" elements in postwar Yugoslavia. Needless to add, such a problem would return with vengeance after the fall of communism, especially during the period of the Yugoslav wars. Yugoslava's attempt to educate peasant women about contraceptives points to the clash of ideology with history. The women, brought up in a patriarchal society, come across as suspicious or unreceptive to pro-choice indoctrination. This does not mean they cannot be changed, but this requires patience and a deeper engagement with their world, which the socialist champions of progress are lacking. At the same time, they are themselves expected to change their way and are subjected to indoctrination, symbolised by the forced cutting of the hair of the male members of the group. This relatively minor act of violence turns out to be only an introduction to greater violence, which the "actors" inflict on each other and which culminates in the killing of Yugoslava by her male partners, and in the burning of the Yugoslav flag. This violence can be seen as stemming from the frustration of the men that the goals of their journey were not being achieved, and that for their female partner this is a proof that they have failed as males.

[11] B. Brecht, Brecht on Theatre: The Development of an Aesthetic, ed. and trans. J. Willet, Hill and Wang,

New York 1964, p. 71. 
By depicting the gap between political programmes and concrete, everyday reality, Žilnik presents himself as suspicious of the two master narratives that shaped Yugoslav history after the Second World War: Yugoslav nationalism and Yugoslav socialism, as well as the doctrine of sexual liberation or hippie culture in a wider sense, which was very influential at the time, both in the West and in the socialist East.[12] Žilnik's criticism of ideologies is not accompanied by any positive programme. In this sense, his cinema parts with that of Brecht, fulfilling perfectly Adorno's programme of autonomous art which refuses to be didactic, meaning trying to be influential at all costs, and hence authoritarian, He appears to accept Adorno's claim that "If art works have any social influence at all, it is not by haranguing, but by changing consciousness in ways that are ever so difficult to pin down." [13]

To add validity to his diagnosis, as well as to make the most of scarce funding, the director presented the situation in a manner pertaining to documentary cinema, using non-professional actors who knew from their own experience the situations in which they appeared. The juxtaposition of a concrete situation and our preconceptions, shaped by the dominant ideology, undermines the latter. One such moment is a conversation with an old man who was in Siberia, presumably sent there as punishment for illegal political activity. We expect him to talk about the political prosecution and harsh living conditions, as this is the dominant discourse on Siberia in other socialist countries. Surprisingly, however, the man says that "Siberia was good," as it provided stability and serenity to his life. Non-professional performers, more than professional actors, who have learnt to follow a script and hide their personalities, bring a certain surplus of meaning, which poses a problem to ideology and ideologues, further revealing the gap between ideology and reality.

Inventory

Žilnik's independent stance led to his films being censored and the director being forced to move to West Germany. He thus became one of this country's many Gastarbeiter, enjoying both the freedoms and constraints of working abroad, such as the need to prove oneself in a foreign country, and the usual lowering of one's demands and conditions. In Germany, Žilnik worked in the collective with such prominent directors as Rainer Werner Fassbinder, Alexander Kluge and Edgar Reitz, the main creators of New German Cinema, on the German version of 'auteur film': Autorenfilm. However, the German Autorenfilm differs from the original Politique del auteurs of the French New Wave, which was based on the "Romantic notion of the author as the creator of the work. Instead, the German Autor was a more political figure who challenged the cinema as an institution while attempting to benefit from the system

[12] D. Beganović, "Changing Fates: The Role of the Hero in Yugoslav Cinema in the Early and Late Sixties," [in:] Retracing Images: Visual Culture after Yugoslavia, eds. D. Šuber, S. Karamanić, Brill, Leiden 2012.
[13] Th. Adorno, "The Autonomy of Art," [in:] The Adorno Reader, ed. B. O'Connor, Blackwells, Oxford 2000 , p. 256. 
in which it operated." [14] Such filmmakers as Alexander Kluge, Wim Wenders, Werner Herzog, Rainer Werner Fassbinder and many others, called themselves "Authors" in order to get money for their projects, but if they wanted to keep their full creative and executive control on their films, they had to take over the producer's tasks, which made them more like small entrepreneurs rather than romanticized authors. [15] Wenders and Kluge are very reflective on these circumstances, and analyse the new state of artist in that particular period. Other themes that unite representatives of this movement include the place of foreigners in German society and class struggle, left-wing terrorism, the Nazi past, and the German prosperity in the 1960s and 1970 .

Žilnik fitted well into the group's agenda, as already in his Yugoslav films he had challenged the dominant cinema, as well as Yugoslav political system and its dominant ideology, while, ultimately, being forced to work within its boundaries and attempting to benefit from it. He was thus equally prepared to criticise Germany and its ideology while also taking advantage of its good points. Moreover, he was interested in many of the topics which fascinated his German colleagues. During his 'German period' he made films about emigration, terrorism and Germany's past. However, he also showed independence from the group, by giving the treatment of specific subjects a particular 'foreign' slant. Hence, in his films on emigration, unlike Fassbinder, who is most interested in the effect of migrant workers on the situation of German citizens, as in Angst essen Seele auf (Ali: Fear Eats the Soul, 1974), Žilnik privileges the position of the foreign migrant/worker. In his Farewell (Abschied, 1975), an emigrant from Serbia who has spent five years working in a BMW factory in Munich recollects his impressions about the city and the country where he worked, and speaks about the new things and habits he has acquired. We see him in transit - he gets on a train at a Munich railway station, ready for his journey south. Such a position not only encapsulates the in-between-ness of a migrant worker, but also of Žilnik himself as a transnational director and a migrant worker.

One of Žilnik's most interesting films from this period is Inventur-Metzstrasse 11 (Inventory, 1975), about a group of people living in one tenement bloc. According to the director, this film was made on almost no budget - the adult participants were paid with bottles of beer and the children with soft drinks. Other members of the crew agreed to take part in the film for free, but they were promised to be paid if the film made money. Normally this is not the case with documentary shorts, but in West Germany of the 1970s, in a reflection of the ideology of the state's support of high art, a special state commission assessed the artistic standard of a film and its producer was paid or received tax release according to the score it received. Žilnik did well in this system,

[14] M. Salokannel, "Cinema in Search of its Authors: On the Notion of Film Authorship in Legal Discourse," [in:] Film and Authorship, ed.
V. Wright Wexman, Rutgers University Press, New Brunswick 2003, pp. 158-160.

[15] Ibidem, p. 159. 
managing to make films practically without interruption and being able to pursue his interests.

Inventory adheres to the premise of Early Works - it advocates the primacy of people over ideas and, at the same time, the relative anonymity and lack of importance of individual people in a specific society - in this case that of West German society, which is also a theme foregrounded in many of Fassbinder's films. The dialectical relation between the individual and society, significance and insignificance, visibility and invisibility, is conveyed by its form. People queuing on a staircase tell the camera in a couple of sentences what they are doing in Germany and for how long they have lived there. Most of them are Gastarbeiter from countries such as Yugoslavia, Turkey and Greece, but some are locals, struggling with everyday hardship. The form of the film points to several ideas. First, it illuminates the fact that 1970 sermany was a multinational and multicultural country, as emphasised by Fassbinder and Kluge. Yet, as I have already mentioned, while for these directors the main issue was the foreign influences on German identity, Žilnik enquires what Germany gives these people, and by the same token, what they were lacking at home that led them to emigrate. The answer is: work and prosperity. In this way, the economic reality comes across as a complex social system - work appears somewhere because it is missing elsewhere, and its lack reflects the problems suffered by a given population. We wonder how miserable their lives had to be in Greece or Yugoslavia if they decided to move to Germany, which offered nothing more than a place in a huge bloc. At the same time, the mode of representing the characters, making them wait for their turn and then telling their story, both highlights their individuality and points to the fact that it is erased in the huge apartment bloc, which can stand for Germany as a whole. The fact that the characters address the camera directly makes us realise that there is a filmmaker behind the project - he made them both stand in a queue and allowed each of them to be the centre of attention for half a minute or so.

In conveying so much in such a limited time, using so little in terms of financial resources, as well as clearly signalling his presence without losing sight of the political issues at hand, Žilnik perfectly fulfils the un-spelled ideal of independent cinema: authorism, miniaturism and political engagement, as well as bridging the gap between Eastern and Western independent cinema.

Old School Capitalism

The German chapter of Žilnik's career finished when he ran into problems with political authorities following Paradise. An Imperialist Tragicomedy (Paradies. Eine imperialistische Tragikomödie, 1976), a film inspired by the fake kidnapping of Peter Lorenz, a right-wing politician from Berlin in the early 1970s. Lorenz spent two weeks being "held captive" by the "Bewegung 2. Juni" terrorist group, and then managed to escape and exploit the case for the benefit of his election campaign. 
The director returned to Yugoslavia in 1976, and, initially unable to make cine-films, found opportunities in television, which afforded more artistic freedom than cinema. In the 1980s, he returned to making full-length fiction films. However, the situation again changed for worse for Žilnik, as for practically all Yugoslav filmmakers, following the Balkan wars and the dissolution of Yugoslavia. The production of films then declined and it became particularly difficult to be politically independent in Serbia, where funds for filmmaking were directly or indirectly controlled by a nationalistic and neoliberal political regime, completely at odds with Žilnik's political views. Yet, he succeeded again, initially using the medium of documentary. One of his best known works completed during Yugoslavia's collapse is the documentary Marble Ass (1995). As Pavle Levi argues, in a manner rarely seen in films from this region, Marble Ass "deconstructs the established homophobic paradigms of the Serb 'national being' by viewing it through the prism of gender and sexuality. Freely mixing video-documentary and 'trash' aesthetics, Žilnik depicts the daily adventures of two actual transvestite prostitutes, Merlyn and Sanela, two Serbs who do not conform to the prevailing patriarchal ideal of the macho male but who, nonetheless, emerge as the sole guardians of sanity, humanity, and sensitivity - in short, normalcy - in the sea of lawlessness, violence, and severe economic frustration." [16]

In 2009, despite a hostile political climate, Žilnik managed to complete a full-length feature film, Stara škola kapitalizma (Old School Capitalism, 2009), which he produced with his partner. Although made on a shoestring budget of about 30,000 Euros, Old School Capitalism comes across as his opus magnum, and is the most ambitious film I know that tackles the relation between lived experience and the ideology that dominated in Eastern Europe after the fall of communism: that of neoliberal capitalism.

The origin of the film lies in the protests of worker-shareholders in the "Sinvoz" and "BEK" factories in Zrenjanin, Serbia, about the way these plants were treated during Serbia's transition from self-management to the new system of neoliberal capitalism. These and other Yugoslav factories went through particular stages during this process: privatisation, bankruptcy, and closing down, which often gave way to new types of enterprises focused on consumption rather than production, such as shopping malls. These workers' situation reflected a wider postcommunist and neoliberal trend toward extreme disciplining of labour and reductions in the workforce, carried out in the name of the socialist East catching up with the West - of becoming modern again. David Kideckel, addressing the concept of the Eastern European "transition" to the European West, argues that "the region's problematic is not too slow a movement to capitalism (as 'transition' would have it) but too fast; not too little capitalism, but too much. Rather than 
postsocialist, it is better understood as 'neo-capitalist', a social system that reworks basic capitalist principles in new, even more inegalitarian ways than the Western model from which it derives." [17] Kideckel and others observe that the poorer and more chaotic an Eastern European country or region was, the more zealously it marched towards the West, understood in such terms. Debilitated by war, Serbia, like Russia or Romania, as well as other countries previously belonging to Yugoslavia, such as Bosnia-Herzegovina and Croatia, fits this model well. In Serbia, the war was used to accelerate the transition to neoliberal capitalism, as wars allow for the suspension of the rights of ordinary citizens. Moreover, the Western perception of Serbs as bloody invaders, attacking neighbouring nations in the name of their national, outdated interests, inevitably rendered the topic of workers' struggle in Serbia to be of little interest to viewers. This might be one reason that Žilnik's film received little exposure or recognition abroad, both in comparison with his earlier works, which were critical of Yugoslav socialism, and his films concerning the Balkan wars, although Old School Capitalism sheds more light on this issue than many "straightforward" war films.

Serbian workers objected to being excluded from vital decisions concerning their factories on the grounds that they were their co-owners. This was the case across the whole of the socialist world, as everything there belonged to the proletariat; however, in Yugoslavia this was officially acknowledged, as the workers there directly invested part of their salaries in the development of their work places. Yet, the new state and the entire apparatus of power rejected this right. As Žilnik himself puts it,

Everything was privatized and then given to the new capitalist buyers and most of those, as we can now see, had been either criminals or those who gained their wealth in Milošević's system, when during the sanctions the state gave privileges to some functionaries. These new owners are aware that the legitimacy of their ownership is questionable.[18]

Branka Curčić observes that the narrative on modernisation and transition was also used to "discursively cleanse" the striking workers as a result of their demanding that their rights be respected, they were labelled Stalinists and criminals:

The workers in Zrenjanin created a double excess in contemporary Serbian reality: they dared to self-organise, demanding their right to work and they have created an interruption in the 'smooth' process of absolute privatisation 'as the ultimate realisation of freedom'. Still activities of this marginalised social group have their dark side as well. In a number of cases

[17] D. Kideckel, "The unmaking of an East-Central European working class," [in:] Postsocialism: Ideals, Ideologies and Practicies in Eurasia, ed. C.M. Hann, Routledge, London 2002, p. 115.
[18] Quoted in: G. Decuir Jr., "Old School Capitalism: An Interview with Zelimir Zilnik," Cineaste, http:// www.cineaste.com/articles/emold-school-capitalismem-an-interview-with-zelimir-zilnik-web-exclusive, 2010 (accessed: May 12, 2012). 
they resulted in death and suicide due to additional pressures workers had to face.[19]

Žilnik wanted to show the workers' success in undermining the logic of transition and the difficulty of building on this success. Initially, he made two "straightforward" documentaries about the protests, but thanks to his receiving additional funding, he managed to incorporate them into a wider narrative which eventually became Old School Capitalism.

The main characters in Old School Capitalism are dispossessed workers, whom Branislav Dimitrijević compares to lumpenproletariat from Marx's The Eighteenth Brumaire of Louis Bonaparte.[20] However, Marx regarded the lumpenproletariat as a reactionary force at the margin of the proletariat. Žilnik, on the other hand, suggests that under postcommunist neoliberalism, at least its Serbian version, the lumpenproletariat expanded - practically the whole old communist industrial working class "lumpen-proletariased." This idea is conveyed at the beginning of the film, where we see a large demonstration in Niš against the closing down of factories and the pauperisation of the Serbian population, alternating between the crowds and a political activist addressing them. The camera then zooms into a smaller group of characters to show their take on the situation. Such a choice fulfils two functions. First, Žilnik shows that only by working in a group are the characters able to effect any change; fragmented, they will be defeated. Second, focusing on a group allows the director to present a variety of ideological perspectives being expressed by the workers. The same thing, importantly, happens on the side of the capitalists: they are a heterogeneous class and succeed only when they are united by their common interests and strategy.

The term which comes to mind to describe the actions of Žilnik's characters is one which he used in Early Works: political theatre. He represents "real life," marked by marches, demonstrations, the occupation of public grounds, public discussions, as a theatre of life - played for the sake of the audience and the actors themselves, who in this way assert their importance and, indeed, their very existence. Participating in this theatre makes the actors realise what unites and what divides them.

On the side of the workers, one disagreement concerns the assessment of the communist past. For some of them it was a time when workers enjoyed a good life; the end of Yugoslavia and the advent of Miloševičs regime changed all this. Others, however, see in Tito's rule the root of the current problems, either because self-management was

[19] B. Curčić, "The Paradigm of Fragility of the Workers' Issue in (post-) Socialist Yugoslavia: Elementary School of Capitalism - On Želimir Žilnik's Latest Film Actions," [in:] For an Idea - Against the Status Quo: Analysis and Systematization of Želimir Žilnik's Artistic Practice, eds. B. Ćurčić et al., Playground produkcija, Novi Sad 2009, pp. 193-194.
[20] B. Dimitrijević, "Concrete Analysis of Concrete Situations: Marxist Education According to Želimir Žilnik," Afterall 25, http://www.afterall.org/ journal/issue.25/concrete-analysis-of-concrete-situations-marxist-education-according-to-elimir-ilnik, 2010 (accessed: May 15, 2012). 
not socialist or not capitalist enough. Equally, some praise capitalism as a system where workers have a better life than in Yugoslavia, pointing to West Germany and the United States as places were ordinary people have a good life. Others, however, mention the poverty in capitalist Africa as a counterpoint to this argument. They agree, however, that the law in Serbia is currently on the side of the rich to an extent it never was before, and they have to fight to change this.

On the other hand, the Serbian capitalists, produced through the privatisation of cooperatively owned enterprises, have to fend off the demanding workers and ensure that their businesses flourish against a background of growing economic and political instability, both in Serbia and globally. For that, they need to navigate the murky waters of military and mafia capitalism. We see that the owners of the bankrupt factories employ a large number of bodyguards as a kind of private army to fend off any attempts at redistribution, try to corrupt local officials to ensure that their products are bought by the state (which elsewhere is politely termed a "public-private partnership") and seek support from Russian tycoons. Postcommunist Russia represents for them the ideal model of business, marked by high returns on investment, a well embedded "public-private" partnership, and, hence, a luxurious lifestyle for Russian businessmen. The situation depicted by the director chimes with the views of David Harvey that under neoliberal conditions the boundary between honest and dishonest business becomes blurred; the capitalists become, as Harvey puts it, "feral." [21] At the same time, the misery and conflict they cause forces them to invest heavily in security to ensure that their private safety and search for surplus value remains unimpeded. Although the material status of the two groups is very different, the lives of both are marked by insecurity and a lack of control and understanding of the world. They do not know what the future will bring them, because they depend on forces larger than themselves, most importantly the global flow of capital. For this reason, many of them regard the visit by the American Vice-President to Serbia as a more important factor in determining their prosperity or fall than their own entrepreneurial skills.

Žilnik brings the two groups together during the workers' attempt to take possession of their factory, stolen from them during privatisation. They dismantle some of the factory buildings in order to sell the bricks and go to their boss's house to demand that he pays their salaries. However, this strategy does not bring the expected outcome, as the capitalist is absent and all they get are bags of groceries from his wife, which can be viewed as a symbol of neoliberal charity. Subsequently a group of young anarchists approaches the disgruntled workers claiming that its members share the workers' objectives. The

[21] D. Harvey, Feral Capitalism Hits the Streets: Reading Marx's Capital with David Harvey (David Harvey blog), http://davidharvey.org/2011/o8/feral -capitalism-hits-the-streets, 2011 (accessed: May 22, 2012). 
workers challenge them to kidnap the factory owner and his associates to prove that they are on their side, which the anarchists do.

Unlike mainstream cinema, which focuses on dramatic action, on this occasion the most dramatic event, capturing the capitalists, comes across as undramatic: as an amateurish performance. The anarchists approach the men camping on the outskirts of their town, put sacks over their heads and push them away in wheelbarrows. The last capitalist is captured near his house and they use a car, but again, unlike in American gangster films, the action and its filming comes across as amateurish. This is conveyed by the "actors" using an old car, and the director using a shaky and frequently out of focus camera, as if there was a particular rapport between the amateurism of the two groups.

Thanks to such means, however, Žilnik conveys the sense of immediacy and authenticity of the actions of his protagonists and of his own position as an author who has no script, no template with which to approach this situation, and instead has to learn about its meanings on the spot. Such an impression is augmented by the way various temporal planes intermingle. First there is the action (in the present tense), and then there is its explanation by referring to earlier events. For example, only after one of the businessmen was captured by the anarchists and then released by his private army, do we learn how the anarchists got the funds to undertake their action. This forces Žilnik to travel to the States, as the anarchists' benefactor turns out to be a Serbian man who left Yugoslavia many years previously and decided to return to his country following the Wall Street crash and general instability in the US. He comes to repay his son, whom he abandoned in the 1970s, and the son uses his inheritance to support the anarchists.

It is worth mentioning that the man who returns to Serbia from the States is played by Lazar Stojanović, best known as the director of Plasticni Isus (Plastic Jesus, 1971), the longest banned film in Yugoslavia. Žilnik most likely invited him to play this role because Stojanović is a dedicated liberal and anti-communist. The fact that his son is played by Branimir Jovanović, the Belgrade philosopher who entertains a completely opposite ideological stance, brings somewhat of an Oedipal dimension in the film to their ideological dispute. Reading it metaphorically, communism is presented as a disobedient son of capitalism.

The most dramatic part of the film takes place in an idled factory where the redundant workers exchange their views with the businessmen. The workers complain about having been robbed of the fruit of their work when their factory was privatised, not being paid for months, having barely enough to live on, and working in jobs that do not suit their qualifications. The capitalists, on the other hand, point to the forces of global capitalism, which made the workers' tools and skills obsolete, and decimated the bosses' profits. For them, the only way to improve the conditions of both parties is by everybody putting their faith in capitalism - investing more and working more in hope of future returns. Such an idea is rejected by the anarchists, who encourage 
the workers to get rid of the capitalists and self-manage by creating a cooperative on the ruins of the factory. However, this idea is not realised because the body guards free their boss and their associates. In the meantime, the leader of the anarchists is taken to jail for publicly burning an American flag.

The workers agree to work in a new enterprise owned by their dishonest boss, this time a large farm, which is also a privatised cooperative. Their trajectory, as represented in the film, is thus one of a downgrading - from being employed as highly skilled workers in a factory producing means of production, which represented a privileged sector under socialist rule, to working as agricultural workers, who are always at the bottom of the pile, as much under socialism as under neoliberal conditions, due to periods of non-work. We also learn that for agricultural workers conditions are especially precarious: they have to work from dawn till dusk, not knowing when and if they will be paid. The privatised farm becomes the scene of a final tragedy - the leader of the group of anarchists, who goes there to encourage the workers to resume their fight, is killed by a plough operated by a worker at the request of the owner of the farm. The capitalist asks the workers to carry on with their tasks and keep the murder a secret or risk being prosecuted for murder, and, reluctantly, they give in to his demand. As in Early Works, the battlefield of ideologies is littered with human corpses. There is even more oppression and misery in the supposedly liberated Serbia than in the old Yugoslavia.

Conclusions

To conclude, I would like to reiterate that Žilnik can serve as a living encyclopaedia of independent cinema, thanks to his working under different political and economic regimes and making films in different countries. At the same time, he shows the ability to retain a specific thematic focus and ideological position in a world which is changing at a frantic speed and does not reward either political or artistic integrity

Žilnik confronts a specific set of ideologies with a specific historical situation as a means to criticise this ideology, the political programmes employing it, as well as the people who naively believe in it or cynically use it. He shows that ideologies are always simplistic; reality is rich, and thus there is a totalitarian element in each ideology. I therefore disagree with the title of the largest publication dedicated to Žilnik so far: For an Idea - Against the Status Quo. No doubt, Žilnik is against the status quo - criticism of it provides the main impulse for his filmmaking. However, he is equally critical about specific ideologies, as they alienate themselves from people, from their embodied experiences. I would rather summarise Žilnik's as being "against an idea and against the status quo." His relentless criticism, or at least scepticism, and irony can frustrate the viewer, who might wonder what Žilnik supports. However, this should be seen in the context of the power of the dominant ideologies in Yugoslavia and the whole socialist world, 
and the attempts to erase all elements which do not adhere to them. His films can thus be viewed as an attempt to bring visibility and a voice to these elements: to views, images and people. Moreover, a mosaic of heterogeneous elements forces the viewer to make up his mind about what he is seeing, to create his own version of events, in short - to be active and independent.

Žilnik's case also points to the need to widen the discussion of independent cinema in order to embrace artists from Eastern Europe and those who do fit a national framework. In my view, such artists should be even placed in the centre of such discussions, as their careers better show the many dimensions of independent filmmaking. 